\title{
Article \\ Control of TRPM3 Ion Channels by Protein Kinase CK2-Mediated Phosphorylation in Pancreatic $\beta$-Cells of the Line INS-1
}

\author{
Alexander Becker ${ }^{1}$, Claudia Götz ${ }^{2}\left(\mathbb{B}\right.$, Mathias Montenarh $^{2}(\mathbb{C})$ and Stephan E. Philipp ${ }^{1, *(1)}$ \\ 1 Experimental and Clinical Pharmacology and Toxicology, Center for Molecular Signaling (PZMS), \\ Saarland University, Building 46, D-66424 Homburg, Germany; AlexBecker5683@hotmail.de \\ 2 Medical Biochemistry and Molecular Biology, Saarland University, Building 44, D-66424 Homburg, Germany; \\ claudia.goetz@uks.eu (C.G.); mathias.montenarh@uks.eu (M.M.) \\ * Correspondence: stephan.philipp@uks.eu
}

Citation: Becker, A.; Götz, C.; Montenarh, M.; Philipp, S.E. Control of TRPM3 Ion Channels by Protein Kinase CK2-Mediated Phosphorylation in Pancreatic $\beta$-Cells of the Line INS-1. Int. J. Mol. Sci. 2021, 22, 13133. https:// doi.org/10.3390/ijms222313133

Academic Editor: Balazs Istvan Toth

Received: 7 October 2021

Accepted: 30 November 2021

Published: 4 December 2021

Publisher's Note: MDPI stays neutral with regard to jurisdictional claims in published maps and institutional affiliations.

Copyright: (c) 2021 by the authors. Licensee MDPI, Basel, Switzerland. This article is an open access article distributed under the terms and conditions of the Creative Commons Attribution (CC BY) license (https:// creativecommons.org/licenses/by/ $4.0 /)$.

\begin{abstract}
In pancreatic $\beta$-cells of the line INS-1, glucose uptake and metabolism induce the openings of $\mathrm{Ca}^{2+}$-permeable TRPM3 channels that contribute to the elevation of the intracellular $\mathrm{Ca}^{2+}$ concentration and the fusion of insulin granules with the plasma membrane. Conversely, glucose-induced $\mathrm{Ca}^{2+}$ signals and insulin release are reduced by the activity of the serine/threonine kinase CK2. Therefore, we hypothesized that TRPM3 channels might be regulated by CK2 phosphorylation. We used recombinant TRPM $3 \alpha 2$ proteins, native TRPM3 proteins from INS-1 $\beta$-cells, and TRPM3-derived oligopeptides to analyze and localize CK2-dependent phosphorylation of TRPM3 channels. The functional consequences of CK2 phosphorylation upon TRPM3-mediated $\mathrm{Ca}^{2+}$ entry were investigated in Fura-2 $\mathrm{Ca}^{2+}$-imaging experiments. Recombinant TRPM $3 \alpha 2$ channels expressed in HEK293 cells displayed enhanced $\mathrm{Ca}^{2+}$ entry in the presence of the CK2 inhibitor CX-4945 and their activity was strongly reduced after CK2 overexpression. TRPM $3 \alpha 2$ channels were phosphorylated by CK2 in vitro at serine residue 1172. Accordingly, a TRPM $3 \alpha 2 \mathrm{~S}_{1172} \mathrm{~A}$ mutant displayed enhanced $\mathrm{Ca}^{2+}$ entry. The TRPM3-mediated $\mathrm{Ca}^{2+}$ entry in INS-1 $\beta$-cells was also strongly increased in the presence of CX-4945 and reduced after overexpression of CK2. Our study shows that CK2-mediated phosphorylation controls TRPM3 channel activity in INS-1 $\beta$-cells.
\end{abstract}

Keywords: transient receptor potential M 3 channels (TRPM3); protein kinase CK2; calcium; glucosestimulated insulin release (GSIS); INS-1

\section{Introduction}

A tight control of the insulin concentration in the blood is essential to maintain blood sugar levels within a narrow range and to prevent diabetes mellitus in humans. $\beta$-cells of the pancreas are unique with regard to their production and release of insulin. Their absence is not compensable by other cells and a reason for type 1 diabetes. The main stimulus for the fusion of insulin-containing granules with the $\beta$-cell membrane and the release of insulin is the elevation of the $\mathrm{Ca}^{2+}$ concentration within the cytosol of the cell $\left(\left[\mathrm{Ca}^{2+}\right]_{\text {cyt }}\right)[1,2]$. This increase is determined by a number of pathways including $\mathrm{Ca}^{2+}$ entry into the cell across the plasma membrane [2]. Among these pathways, the opening of voltage-gated $\mathrm{Ca}^{2+}$ channels (Cav) is regarded as the main mechanism for the rise of $\left[\mathrm{Ca}^{2+}\right]_{\text {cyt }}[1,2]$. These channels are highly permeable for $\mathrm{Ca}^{2+}$ but almost impermeable for monovalent cations allowing a selective inflow of $\mathrm{Ca}^{2+}$ even under physiological ion conditions [3]. The opening of Cav channels is triggered by voltage changes, i.e., the depolarization of the membrane potential. Following the uptake and metabolism of glucose and the production of ATP, this membrane depolarization can be evoked by the closure of ATP-dependent potassium channels. However, any ion motion across the plasma membrane affecting the membrane potential could have an effect on $\left[\mathrm{Ca}^{2+}\right]_{c y t}$ and, thus, on insulin secretion [1]. 
We recently showed that mice lacking transient receptor potential melastatin 3 (TRPM3) proteins display impaired glucose tolerance after intraperitoneal and oral administration of glucose, suggesting an essential role of TRPM3 in insulin release [4]. TRPM3 proteins build $\mathrm{Ca}^{2+}$ permeable channels [5-7] that can be activated by the neurosteroid pregnenolone sulfate (PS, [8]) as well as the synthetic ligand CIM0216 [9]. These agonists open two alternative ion permeation pathways that are determined by the length of the pore loop of the participating TRPM3 isoforms [9,10]. Whereas PS is an effective agonist of short pore isoforms, long pore loop variants are insensitive to PS but sensitive to CIM0216 [10]. The activity of TRPM3 channels is enhanced by membrane phosphoinositides [11,12] and inhibited by $\mathrm{Ca}^{2+} /$ calmodulin $[13,14]$. They belong to the TRP family of cation channels encompassing 28 members in mammals and subdivided into 6 subfamilies (TRPC1-7, TRPV1-6, TRPM1-8, TRPA1, TRPP2,3,5, and TRPML1-3 [15]). In neurons, where their activity is tightly controlled by the $G \beta \gamma$-subunits of G-protein coupled receptors [16-19], they serve as temperature-dependent pain sensors [20]. TRPM3 channels are also expressed in primary pancreatic $\beta$-cells [8]. There, they build an influx pathway for $\mathrm{Zn}^{2+}$ ions that are co-released with insulin [21] and they enhance insulin release in response to PS [8,9]. In $\beta$-cells of the line INS-1, TRPM3 channels get also directly activated by elevated levels of glucose leading to increased $\left[\mathrm{Ca}^{2+}\right]_{\mathrm{cyt}}$ and insulin release [4]. In addition, TRPM3 channels trigger the activity of Cav channels, so that both channels synergistically increase $\left[\mathrm{Ca}^{2+}\right]_{\mathrm{cyt}}$ and insulin release [4]. Recently, we found $\left[\mathrm{Ca}^{2+}\right]_{\text {cyt }}$ and insulin release strongly increased after inhibition of the serine/threonine kinase CK2 with CX-4945 or quinalizarin, and we identified Cav2.1 channels as a substrate of CK2 phosphorylation [22], suggesting a modulating role of CK2-mediated Cav channel phosphorylation in insulin release.

Similar to Cav channels, TRPM3 channels contain a number of putative target sites for CK2 phosphorylation, and we hypothesized that CK2 phosphorylation may control the activity of TRPM3 channels, too. Here, we show for the first time that the activity of TRPM3 channels depends on phosphorylation. Recombinant TRPM $3 \alpha 2$ channels as well TRPM3 channels endogenous to INS-1 $\beta$-cells display enhanced activity after CK2 inhibition and reduced activity after CK2 overexpression. TRPM $3 \alpha 2$ channels are phosphorylated in vitro by CK2 at serine residue 1172. This phosphorylation significantly reduces TRPM3mediated $\mathrm{Ca}^{2+}$ entry and might, therefore, contribute to the TRPM3-mediated control of insulin release.

\section{Results}

\subsection{CK2 Phosphorylates TRPM3}

First, we tested whether CK2 phosphorylates TRPM3 proteins in vitro. We chose the TRPM3 isoform TRPM3 $\alpha 2$, which appeared to be most abundant in INS1 cells [4]. HEK293 cells, which do not express TRPM3 endogenously [5], were transfected with the TRPM $3 \alpha 2$ cDNA. Three days later, proteins were precipitated using monoclonal antiTRPM3 antibodies and incubated with $\left[\gamma^{-32} \mathrm{P}\right] \mathrm{ATP}$ in the presence or absence of added recombinant CK2 (Figure 1A). Likewise, we detected strong phosphorylation of $\sim 200 \mathrm{kD}$ proteins in TRPM3-transfected HEK293 cells that were not detected in HEK control cells or in the absence of CK2. The data show that TRPM3 proteins get phosphorylated by CK2 in vitro.

However, after longer exposure of the autoradiograph, we got a faint signal from proteins of the same molecular mass even without CK2 addition (not shown), indicating that kinases endogenous to HEK cells associate with and phosphorylate TRPM3. To analyze whether the associated kinase is indeed protein kinase CK2, we repeated the experiments under conditions that were favorable for CK2. CK2 is one of the rare kinases that can use GTP as phosphate donor with nearly the same efficiency as ATP [23]. We immunoprecipitated proteins from HEK293 or HEK293 cells of the line HEK $\alpha 2$ that stably overexpress TRPM $3 \alpha 2$ proteins [24] either with mono- or polyclonal TRPM3 antibodies and incubated the immunoprecipitates with $\left[\gamma_{-}{ }^{32} \mathrm{P}\right]$ GTP. With both anti-TRPM3 antibodies, we observed in immunoprecipitates of HEK $\alpha 2$ but not HEK293 control cells a phosphorylated protein 
with a molecular mass of $\sim 200 \mathrm{kD}$ (Figure 1B,C). We conclude that kinases endogenous to HEK $\alpha 2$ cells associate with TRPM3 channels and co-immunopurify together with TRPM3. These kinases can use GTP for phosphorylation.

A

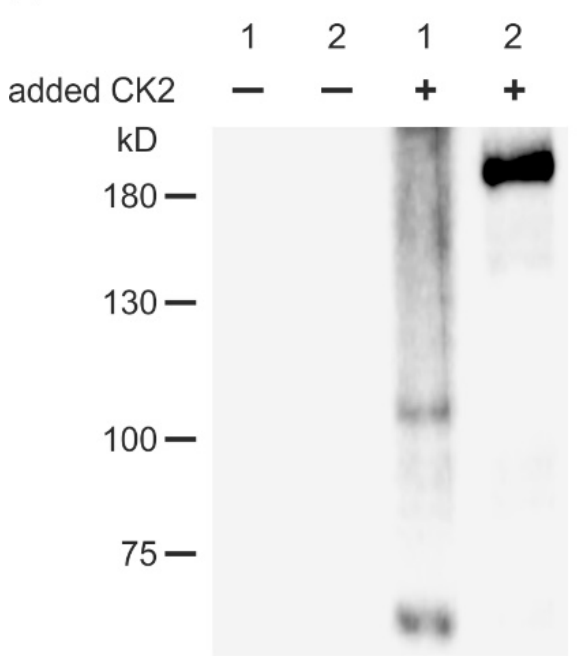

B

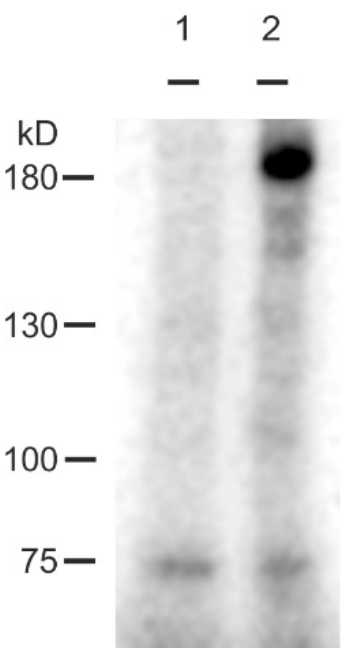

C

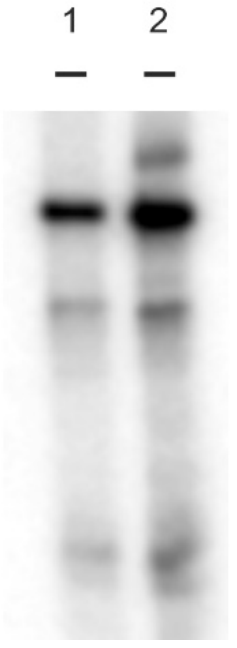

$\mathrm{D}$

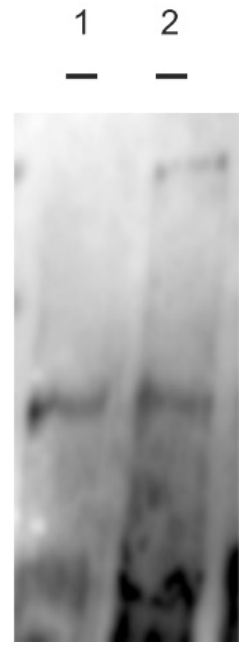

Figure 1. CK2 phosphorylates TRPM3 channels. Immunoprecipitated proteins from HEK293 cells (1) and TRPM3 2 expressing HEK293 cells (2) were incubated in the presence (+) or absence (-) of added CK2 and separated by gel electrophoresis. (A) Autoradiograph (short exposure, $\sim 2 \mathrm{~h}$ ) of proteins that were immunoprecipitated using monoclonal anti-TRPM3 antibodies and phosphorylated in the presence of $\left[\gamma_{-}{ }^{32} \mathrm{P}\right] \mathrm{ATP}$. (B) The same as in (A) but in the presence of $\left[\gamma_{-}{ }^{32} \mathrm{P}\right]$ GTP and the absence of added CK2 (long exposure, $\sim 24 \mathrm{~h}$ ). (C) Same as in (B), but proteins were immunoprecipitated using polyclonal anti-TRPM3 antibodies. (D) Same as in (C), but separated proteins were blotted onto a PVDF membrane and analyzed with a phospho-CK2 substrate motif antibody.

In order to strengthen the evidence that the associated kinase is protein kinase CK2, immunoprecipitated proteins were subjected after incubation with GTP to an immunoblot analysis using phosphospecific antibodies, which recognize a CK2 substrate motif in its phosphorylated form. We observed a distinct signal at the appropriate molecular mass for TRPM3 only in immunoprecipitates of HEK $\alpha 2$ cells (Figure 1D). Thus, the coimmunoprecipitated kinase can use GTP and phosphorylates TRPM3 at consensus sequences, which are typical motifs for the acidophilic kinase CK2. We suggest that the associated kinase is protein kinase CK2.

\subsection{CK2 Phosphorylation Inhibits TRPM3-Mediated $\mathrm{Ca}^{2+}$ Entry}

Does phosphorylation change TRPM3-driven processes? To answer this question, we analyzed HEK $\alpha 2$ cells in Fura- $2 \mathrm{Ca}^{2+}$ imaging experiments. To block the endogenous CK2 present in these cells [25], we used the CK2 antagonist CX-4945. Addition of $10 \mu \mathrm{M}$ CX-4945 directly to HEK $\alpha 2$ cells did not change the intracellular $\mathrm{Ca}^{2+}$ concentration (data not shown), demonstrating that CX-4945 has no immediate agonistic effect on TRPM3 channels or other calcium entry pathways in HEK293 cells. Then, we pre-incubated the cells for $30 \mathrm{~min}$ in $10 \mu \mathrm{M} \mathrm{CX}-4945$, washed them twice, and analyzed them before and after stimulation with the TRPM3 agonists pregnenolone sulfate (PS) and CIM0216. We found the TRPM3-mediated $\mathrm{Ca}^{2+}$ entry strongly enhanced when the cells were pretreated with the CK2 inhibitor, indicating that CK2-dependent phosphorylation inhibits TRPM $3 \alpha 2$ channels (Figure 2A). To confirm that finding, we analyzed HEK $\alpha 2$ cells overexpressing CK2 $\alpha$. Cells were transfected with cDNA encoding fusion proteins consisting of the enhanced green fluorescent protein (EGFP) and CK2 $\alpha$. Green fluorescent cells were compared to non-fluorescent neighboring cells of the same dish and to non-transfected cells (Figure 2B). 
Introduction of recombinant CK2 $\alpha$ reduced the PS/CIM0216-induced increase of $\left[\mathrm{Ca}^{2+}\right]_{\mathrm{cyt}}$ significantly, demonstrating again that CK2 phosphorylation modulates TRPM3 channels.

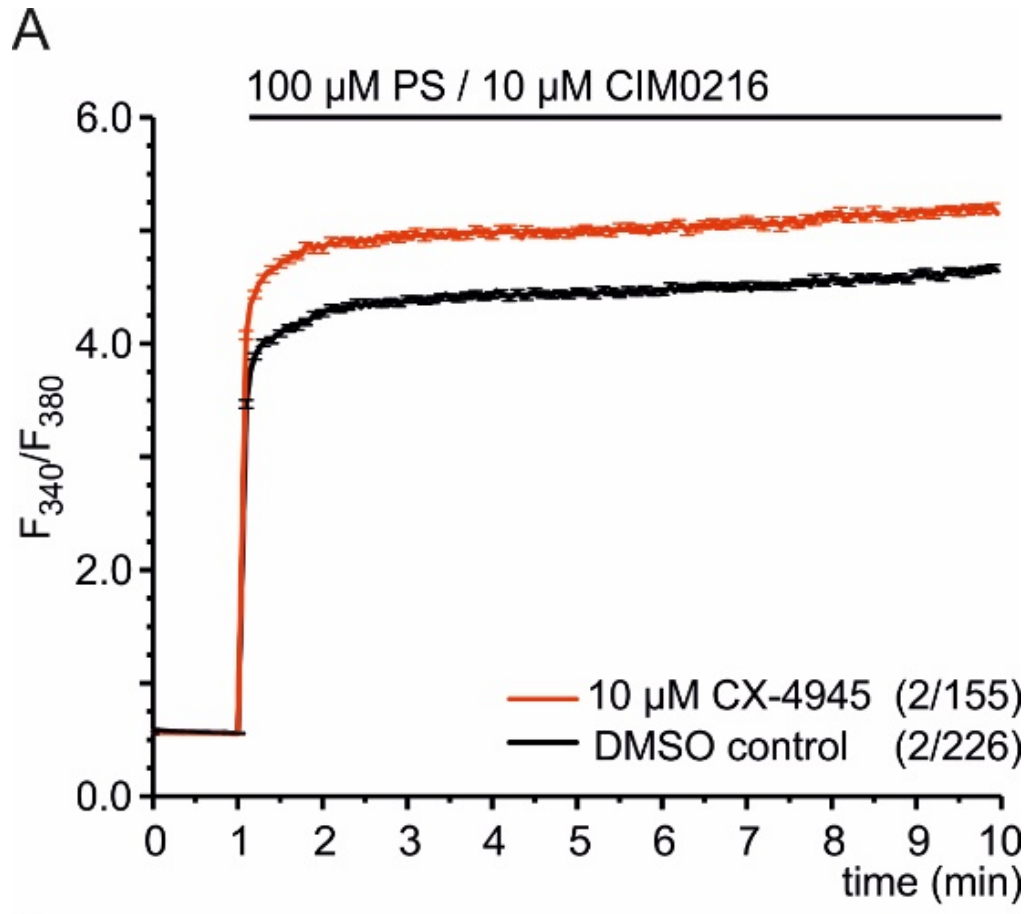

B

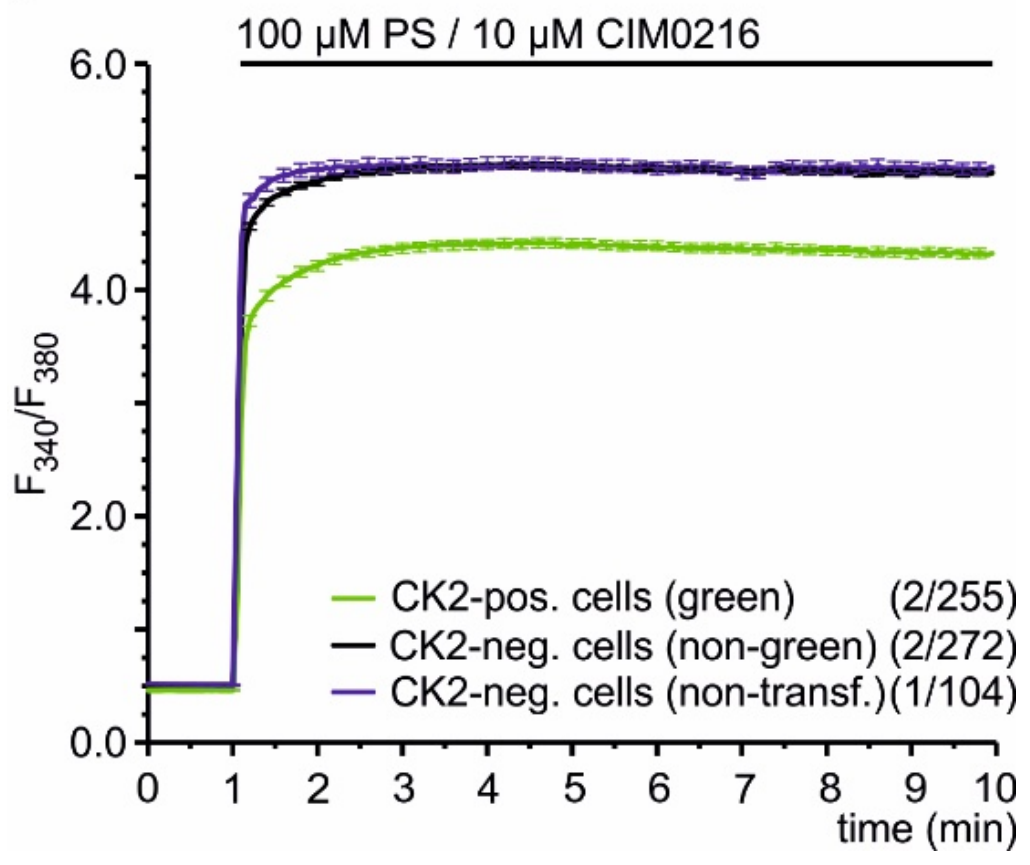

Figure 2. TRPM3-mediated $\mathrm{Ca}^{2+}$ signals are inhibited by CK2. (A) $\mathrm{Ca}^{2+}$ signals induced by PS/CIM0216 in stable TRPM3 $\alpha 2$-overexpressing HEK293 cells (HEK $\alpha 2)$ in the presence (red trace) or absence (black trace, solvent DMSO only) of the CK2 inhibitor CX-4945. Cells were pre-incubated for 30 min in CX-4945 or DMSO. (B) Fura-2 $\mathrm{Ca}^{2+}$ imaging experiments with HEK $\alpha 2$ cells transfected with cDNA encoding EGFP-CK2 $\alpha$ fusion proteins and stimulated with pregnenolone sulfate (PS)/CIM0216. $\mathrm{Ca}^{2+}$ signals of green fluorescent cells (green) were compared to non-green cells (black) of the same dish as well as to non-transfected cells (blue). The number of independent experiments and the total number of analyzed cells are each indicated in brackets. 


\subsection{Identification of CK2 Phosphorylation Sites in TRPM3 Proteins}

TRPM3 proteins contain 32 amino acid motifs of the sequence S/T XX D/E, in which either a serine or a threonine residue could be a target of CK2 phosphorylation (Figure 3A). We systematically analyzed these putative phosphorylation sites within the complete murine TRPM3 amino acid sequence (including all 28 protein-coding exons) by in vitro phosphorylation of a TRPM3 peptide library (Figure 3B). For that purpose, pentadecapeptides containing the putative serine/threonine targets in their center were synthesized on cellulose membranes. As controls, corresponding peptides, carrying non-phosphorylatable alanine residues instead, were synthesized next to them. Control peptides of the sequence RRRDDDSDDD (positive control) and RRRDDDADDD (negative control) were also included. Filters were incubated with radiolabeled $\left[\gamma^{-32} \mathrm{P}\right] \mathrm{ATP}$ in the presence or absence of recombinant $\mathrm{CK} 2$. The positive control peptide displayed strong radiolabeling that was absent when serine residues were replaced with alanine (Figure 3B).

An equally strong phosphorylation exhibited a TRPM3 peptide with the sequence CRWRKHES $_{1280}$ DQDERDY containing the residue serine $1280\left(\mathrm{~S}_{1280}\right)$. This signal was absent in the control peptide with $S_{1280}$ replaced by alanine indicating specific phosphorylation of $S_{1280}$. The peptides containing the residues $S_{124}, T_{1395}, S_{1765}$, and $S_{1789}$ displayed phosphorylation signals, too. However, the corresponding control peptides displayed similar signals, indicating non-specific phosphorylation of non-canonical phosphorylation sites within the sequences or unspecific binding of $\left[\gamma_{-}{ }^{32} \mathrm{P}\right] \mathrm{ATP}$. We found weak phosphorylation of the pentadecapeptide EKDDRFNS ${ }_{1322} S_{1323}$ NDERIR, which disappeared, however, as soon as one of the two serine residues was mutated. In summary, at least in experiments using in vitro phosphorylation of pentadecapeptides, $S_{1280}$ appeared as the only single TRPM3 residue that was specifically phosphorylated by CK2.

\subsection{Phosphorylation of $S_{1280}$ Reduces TRPM3 Channel Activity}

We next asked whether the phosphorylation of $S_{1280}$ may change TRPM3 channel activity. To answer this question, we mutated the corresponding serine residue $S_{1172}$ of the most common isoform TRPM $3 \alpha 2$ to alanine and compared the $\mathrm{Ca}^{2+}$ entry through the mutant channel TRPM $3 \alpha 2 S_{1172}$ A to that through the wild-type channel. We did not detect any difference of expression between the wild-type and the mutated TRPM $3 \alpha 2$ protein (Figure 4A). However, we observed an increased $\left[\mathrm{Ca}^{2+}\right]_{\mathrm{cyt}}$ in HEK293 cells transfected with the mutant already before stimulation of the channels, indicating an increased basal activity of TRPM $3 \alpha 2$ channels in the absence of phosphorylation of amino acid residue 1172 (Figure 4B). After full stimulation of the channels with the TRPM3 agonists, PS and CIM2016, the difference in $\mathrm{Ca}^{2+}$ entry between mutant and wild-type-expressing cells was strongly enhanced showing that phosphorylation of $S_{1172}$ in the TRPM $3 \alpha 2$ variant controls its maximal activity. We conclude that phosphorylation of $\mathrm{S}_{1280}$ is a regulatory mechanism to limit basal and maximum TRPM3-mediated $\mathrm{Ca}^{2+}$ entry.

\subsection{CK2 Controls TRPM3 Channels in INS-1 $\beta$-Cells}

The data shown so far describe the interplay of CK2 and recombinant TRPM $3 \alpha 2$ channels. To analyze the influence of CK2 upon endogenous TRPM3 channels, we used pancreatic $\beta$-cells of the line INS-1 cells and examined the effects of the CK2 antagonist, CX-4945, upon the TRPM3-mediated $\mathrm{Ca}^{2+}$ entry evoked by PS and CIM0216 (Figure 5A). Similar to HEK $\alpha 2$ cells, INS- 1 cells did not show any change of $\left[\mathrm{Ca}^{2+}\right]_{\mathrm{i}}$ after direct addition of $10 \mu \mathrm{M}$ CX-4945 (data not shown) indicating that CX-4945 does not act as a direct agonist of $\mathrm{Ca}^{2+}$ entry pathways in these cells. 
A

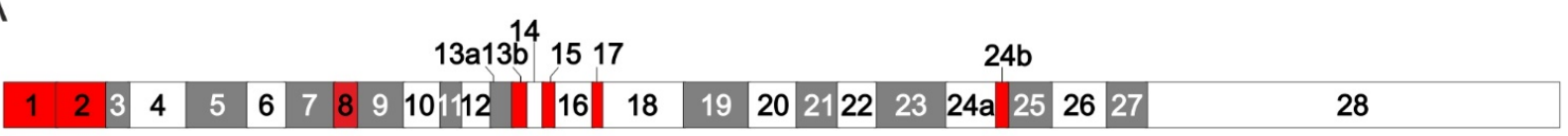

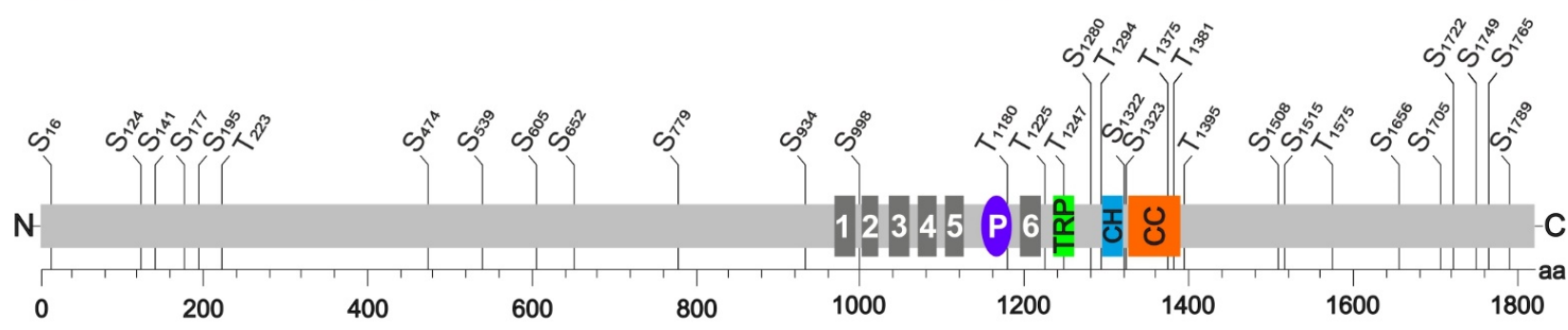

B

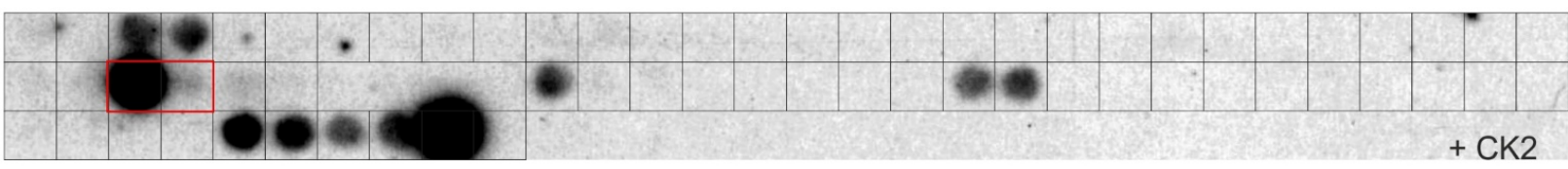

$\mathrm{S}_{16} \mathrm{~A}_{16} \mathrm{~S}_{124}\left|\mathrm{~A}_{124} \mathrm{~S}_{141}\right| \mathrm{A}_{141}\left|\mathrm{~S}_{177}\right| \mathrm{A}_{177} \mathrm{~S}_{195}\left|\mathrm{~A}_{195}\right| \mathrm{T}_{223}\left|\mathrm{~A}_{223}\right| \mathrm{S}_{474} \mathrm{~A}_{474} \mathrm{~S}_{539}\left|\mathrm{~A}_{539} \mathrm{~S}_{605}\right| \mathrm{A}_{605} \mathrm{~S}_{652}\left|\mathrm{~A}_{652} \mathrm{~S}_{779} \mathrm{~A}_{779}\right| \mathrm{S}_{934} \mathrm{~A}_{934} \mathrm{~S}_{998}\left|\mathrm{~A}_{998} \mathrm{~T}_{1180}\right| \mathrm{A}_{1180} \mathrm{~T}_{1225} \mid \mathrm{A}_{1225}$

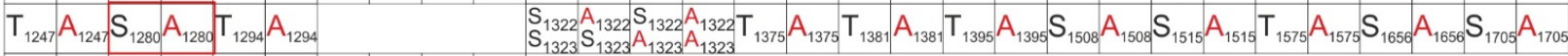
$S_{1722} A_{1722} S_{1749} A_{1749} S_{1765} A_{1765} S_{1789} A_{1789}$ con con

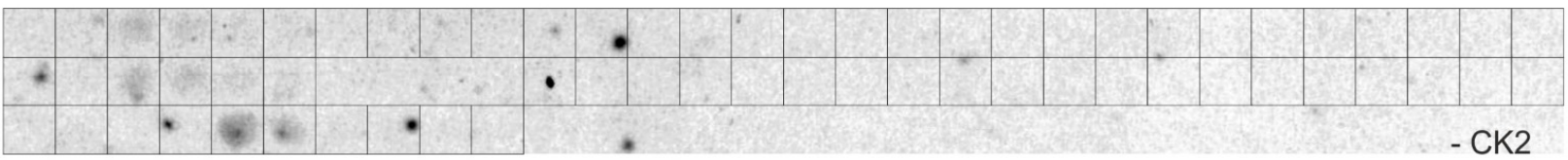

C

TRP domain

S1280 (corresponding to S1172 of TRPM3 $\alpha 2$ )

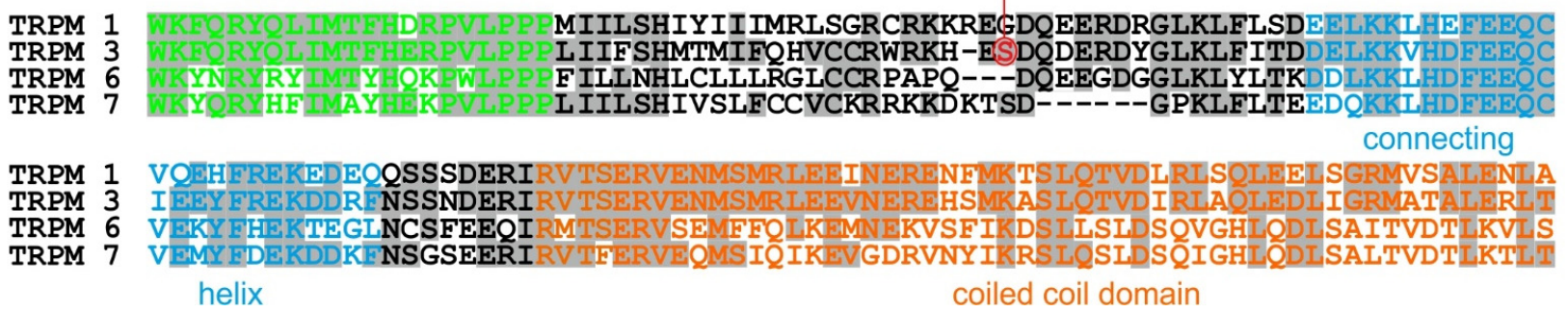

Figure 3. CK2 phosphorylation of a single serine residue of TRPM3. (A) Localization of putative CK2 phosphorylation sites within TRPM3 proteins. The mouse Trpm3 gene comprises 28 exons (upper panel, [26]). Alternative $N$-termini of $\alpha$-isoforms and $\beta$-isoforms are encoded by exon 1 and exon 2, respectively (shown in red). Likewise, as a result of alternative splicing, the protein regions encoded by exons $8,13 \mathrm{~b}, 15,17$, and $24 \mathrm{~b}$ (shown in red) are absent in several isoforms. The organization of domains of the encoded TRPM3 proteins (light gray bar) is shown below true to scale. Well-conserved domains such as transmembrane helices S1-S6 (dark gray), channel pore (P, violet) TRP domain (TRP, green) a N/C-terminal connecting helix $(\mathrm{CH}$, blue), and a coiled coil domain (CC, orange) are indicated [15]. The positions of 23 serine (S) and 9 threonine (T) amino acid residues (aa), representing putative CK2 phosphorylation sites, are indicated by numbers. (B) Analysis of all putative CK2 phosphorylation sites within TRPM3 reveals selective phosphorylation of $\mathrm{S}_{1280}$. In all, 15 mer-peptides each comprising one of the 32 putative phosphorylation sites (S/T XX D/E) within the complete TRPM3 amino acid sequence (including all known exons) were synthesized on cellulose membranes. Corresponding peptides carrying $\mathrm{S} / \mathrm{T}$ to A mutations were synthesized next to them, each. Membranes were incubated with $\left[\gamma_{-}{ }^{32} \mathrm{P}\right] \mathrm{ATP}$ in the presence (+CK2) or absence (-CK2) of protein kinase CK2. Peptides of the sequence RRRDDDSDDD/RRRDDDADDD served as positive (con+) and negative (con-) controls, respectively. Note the selective phosphorylation of $S_{1280}$ (highlighted by a red rectangle). (C) $\mathrm{S}_{1280}$ (highlighted in red, corresponding to $\mathrm{S}_{1172}$ of TRPM3 $\alpha 2$ ) is not conserved within TRPM proteins as shown by sequence alignment of mouse TRPM3 (NP_001030319.1) with its closest relatives TRPM1 (NP_001034193.2), TRPM6 (NP_700466.1), and TRPM7 (NP_067425.2). Amino acid residues identical to TRPM3 are highlighted by gray backgrounds. Amino acid residues belonging to the TRP-domain [27], the connecting helix [27], and the coiled coil domain [28] are labeled in green, blue, and orange, respectively. 

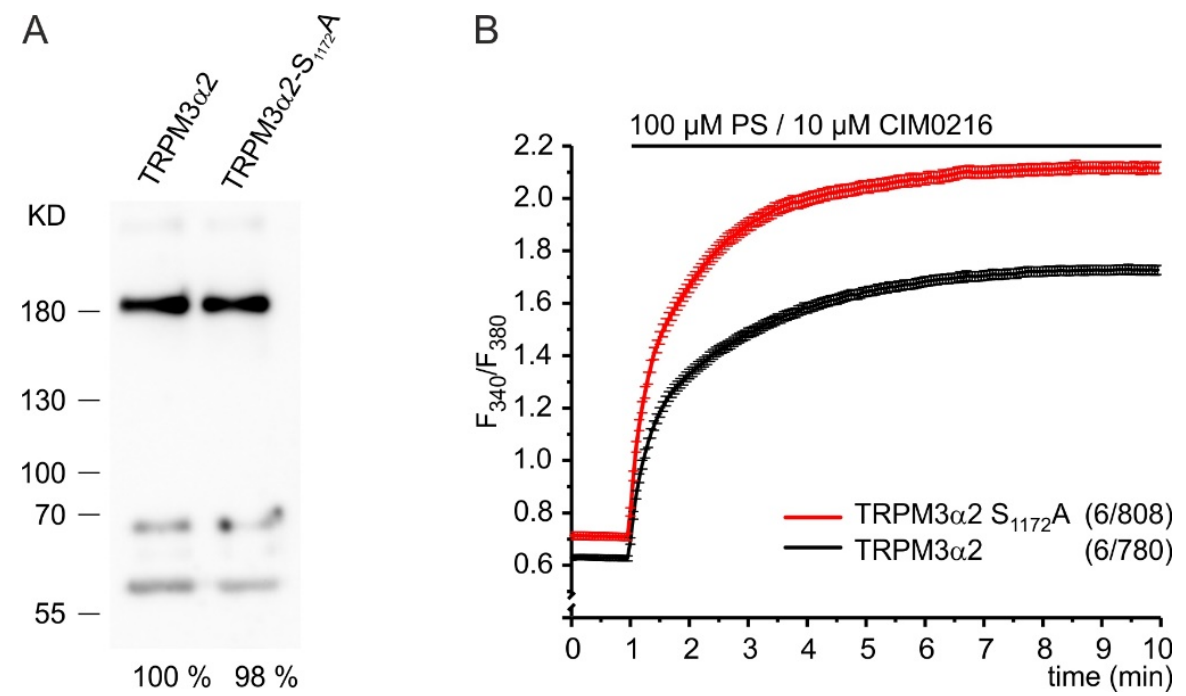

Figure 4. Replacement of serine residue 1172 with alanine strongly enhances TRPM3-mediated Ca ${ }^{2+}$ entry. (A) Western blot analysis using monoclonal anti-TRPM3 antibodies of immunoprecipitated proteins from equal numbers of FACS-sorted cells transfected as described in (B). Densitometric analysis of signals at the appropriate molecular mass for TRPM3 revealed relative signal intensities (\%) as indicated beneath the blot. (B) Fura-2 $\mathrm{Ca}^{2+}$ imaging experiments of green fluorescent HEK293 cells analyzed $48 \mathrm{~h}$ post transfection of plasmids allowing the bicistronic expression of the green fluorescent protein and TRPM $3 \alpha 2$ (black trace) or TRPM $3 \alpha 2 \mathrm{~S}_{1172} \mathrm{~A}$ (red trace), respectively. The duration of the presence of pregnenolone sulfate (PS) and CIM0216 is shown. The number of independent experiments and the total number of analyzed cells are indicated in brackets.

At a concentration of $10 \mu \mathrm{M}$, the TRPM3 agonist, CIM0216, has been shown to activate TRPA1 channels, too [9]. These channels have been proposed to induce basal insulin release from $\beta$-cells and may be expressed in INS-1 cells as well [29]. Therefore, we tested next whether co-stimulation of INS-1 cells with $100 \mu \mathrm{M}$ PS and $1 \mu \mathrm{M}$ CIM0216 provoked $\mathrm{Ca}^{2+}$ entry through any other channel than TRPM3. Three independent TRPM3-deficient INS-1 cell lines, INS-1 M3KO-1, INS-1 M3KO-2, and INS-1 M3KO-3 [4], did not show a significant increase of $\left[\mathrm{Ca}^{2+}\right]_{\mathrm{cyt}}$ after the addition of $100 \mu \mathrm{M}$ PS and $1 \mu \mathrm{M}$ CIM0216. (Figure 5A). In contrast to these TRPM3 knockout lines, we observed a strong and immediate increase of $\left[\mathrm{Ca}^{2+}\right]_{\text {cyt }}$ in wild-type INS- 1 cells, demonstrating that, under these condition, $\mathrm{Ca}^{2+}$ entry is exclusively induced by TRPM3 channels.

This increase was significantly enhanced after pre-incubation with CX-4945, strongly indicating for one thing that TRPM 3 channels in INS- $\beta$-cells are targets of CK2-mediated phosphorylation and for another that CK2 phosphorylation reduces TRPM3-dependent $\mathrm{Ca}^{2+}$ entry. To further support this conclusion, we transfected INS-1 cells with cDNA encoding EGFP-CK2 fusion proteins and compared the TRPM3-mediated $\mathrm{Ca}^{2+}$ entry in green fluorescent cells to that in non-fluorescent neighboring cells (Figure 5B). Before stimulation, we observed increased $\mathrm{Ca}^{2+}$ levels in cells expressing green fluorescent CK2 fusion proteins. This might be related to increased CK2 phosphorylation of proteins different from TRPM3 in INS-1 cells. In contrast, after the stimulation of TRPM3 channels with PS and CIM0216, we found strongly reduced $\mathrm{Ca}^{2+}$ levels in CK2-expressing cells, again suggesting that CK2 phosphorylation inhibits TRPM3 channels in INS- $1 \beta$-cells. 
A

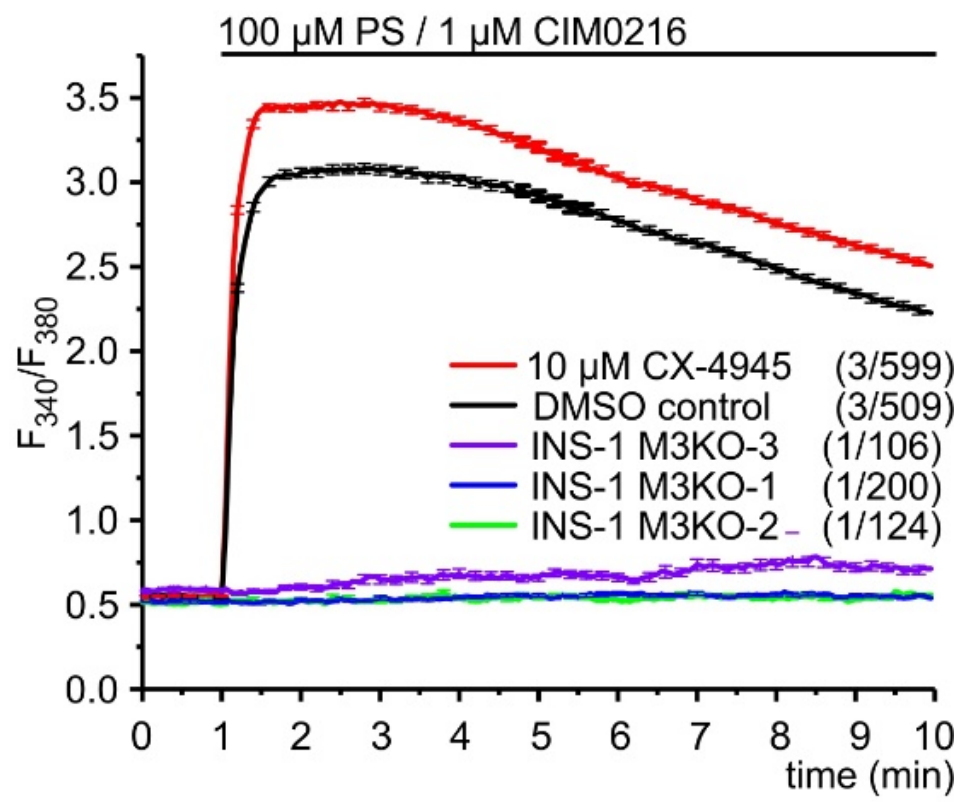

B

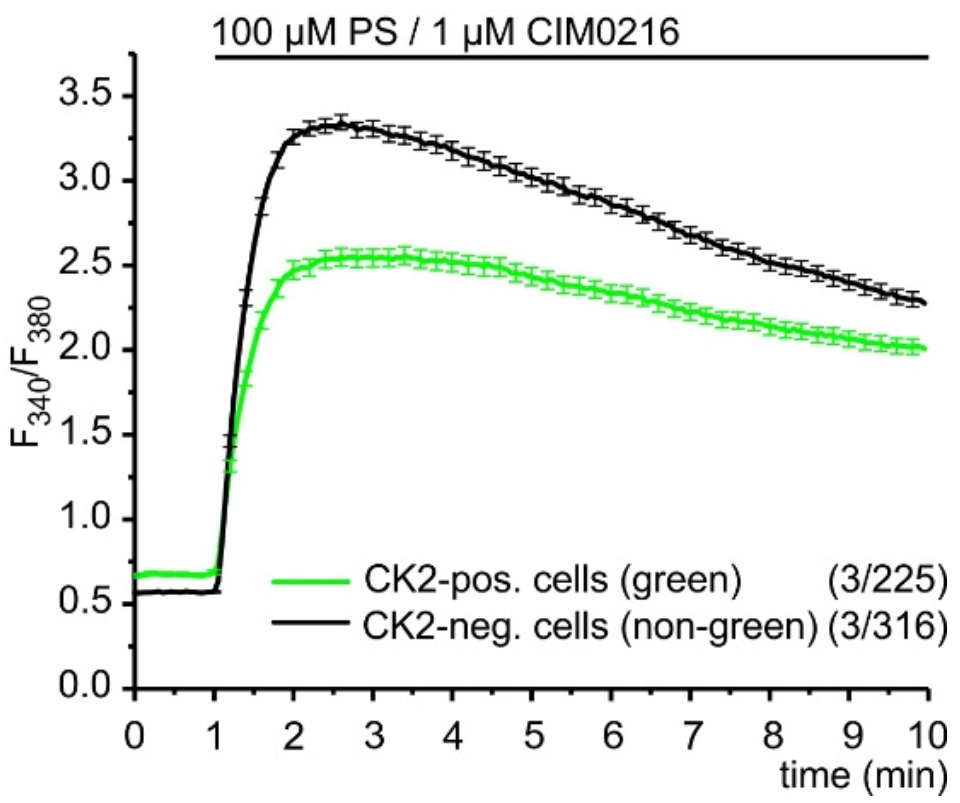

Figure 5. Protein kinase CK2 controls TRPM3-mediated $\mathrm{Ca}^{2+}$ signals in INS- $1 \beta$-cells. (A) The pregnenolone sulfate (PS)/CIM0216-induced $\mathrm{Ca}^{2+}$ entry in INS-1 cells was exclusively induced by TRPM3 and increased after treatment with the CK2 inhibitor, CX-4945. Cells from three independent TRPM3-deficient INS-1 cell lines (green, blue, and violet traces) did not respond to the TRPM3 agonists PS $(100 \mu \mathrm{M})$ and CIM0216 $(1 \mu \mathrm{M})$. In contrast, wild-type INS-1 cells that were pre-incubated for $30 \mathrm{~min}$ in $10 \mu \mathrm{M}$ CX-4945 (red trace) showed increased PS/CIM0216-induced $\mathrm{Ca}^{2+}$ signals compared to that in control cells treated with solvent (DMSO) only (black trace). (B) Pregnenolone sulfate (PS)/CIM0216-induced $\mathrm{Ca}^{2+}$ signals in INS-1 cells were reduced after the introduction of recombinant CK2 $\alpha$. INS-1 cells were transfected with pEGFP-CK $2 \alpha$. Green fluorescent cells expressing EGFP-CK $2 \alpha$ fusion proteins (green trace) were compared to non-green cells of the same dish (black trace). The number of independent experiments and the total number of analyzed cells are indicated in brackets, each. 


\section{Discussion}

\subsection{TRPM3 Channels Are Controlled by Phosphorylation}

Phosphorylation is a common regulatory mechanism to control most cellular pathways, and almost all TRPC and TRPV channels have been described as targets of a number of kinases [30]. However, only little is known about the phosphorylation of TRPM channels. For TRPM7, it has been shown that gating is inhibited by protein kinase A due to the phosphorylation of the residue $S_{1269}$ c-terminal to the coiled coil domain [31]. For TRPM4 channels, the $\mathrm{Ca}^{2+}$ sensitivity has been shown to be regulated by protein kinase $\mathrm{C}$-dependent phosphorylation at $\mathrm{S}_{1152}$ and $\mathrm{S}_{1145}$ within the C-terminus of the protein [32] and that casein kinase 1 (CK1)-mediated phosphorylation of $\mathrm{S}_{839}$ is responsible for the basolateral localization of this channel in polarized epithelial cells [33]. Very recently, constitutive phosphorylation of four C-terminal serine residues has been identified as a key regulator of TRPM8 channels [34]. TRPM3 channels, however, have never been described as targets of phosphorylation.

Here, we show for the first time that TRPM 3 channels are controlled by phosphorylation. We found TRPM3 to be phosphorylated by CK2, but TRPM3 might also be the target of other kinases that need to be identified. Among 32 putative CK2 phosphorylation sites present in TRPM3 proteins, we only found one single residue $\left(S_{1280}\right)$ to be selectively phosphorylated. A comprehensive analysis of the phosphoproteome of murine pancreatic islets and Min6 insulinoma cells [35] as well as INS-1 cells [36] by mass spectrometry of peptides obtained by tryptic digestion did not reveal phosphorylation of this residue. This might be related to the low $\mathrm{pI}$ and molecular mass of the $\mathrm{S}_{1280}$-containing tryptic peptide HES $_{1280}$ DQDER and, therefore, might have been overlooked. Due to our experimental approach of testing short TRPM3-derived peptides in vitro, the identification of $S_{1280}$ does not rule out CK2-phosphorylation of additional TRPM3 residues in vivo. We also observed phosphorylation of a peptide, EKDDRFNS ${ }_{1322} \mathrm{~S}_{1323}$ NDERIR, containing two adjacent serine residues, which was undetectable when both residues were exchanged with alanine. However, this phosphorylation appeared to be less prominent and dependent on the presence of both residues since phosphorylation disappeared as soon as one of the two residues was mutated. This is rather unexpected for target sites of CK2 [37,38] and might, therefore, rely on unspecific interaction of CK2 with this peptide.

How the phosphorylation of $\mathrm{S}_{1280}$ reduces TRPM3-mediated $\mathrm{Ca}^{2+}$ entry remains an open question. An indirect mechanism leading to diminished levels of TRPM3 at the plasma membrane could be a plausible explanation. Similar to TRPM3, CK2 phosphorylates a single serine residue $\left(\mathrm{S}_{812}\right)$ within the C-terminus of TRPP2 channels. This phosphorylation enhances the binding of phosphofurin acidic cluster sorting protein (PACS)-1 and PACS-2 to acidic clusters surrounding the phosphorylation site [39]. Binding of PACS proteins reduces the presence of TRPP2 channels at the plasma membrane due to their retrieval from the Golgi apparatus to the endoplasmic reticulum. Since acidic clusters were identified within many other ion channels and since (among others) TRPV4 channels bind PACS proteins as well, the binding of PACS molecules to phosphorylatable acidic clusters of ion channels has been proposed as an important mechanism for the sorting of ion channels to cellular compartments and the control of their activity [39]. Similar to $\mathrm{S}_{812}$ of TRPP2, $\mathrm{S}_{1280}$ of TRPM3 is flanked by acidic aspartic and glutamic acid residues and we observed enhanced fluorescence inside the cell after overexpression of TRPM3-EGFP fusion proteins, e.g., in INS-1 cells (unpublished observation). Thus, after phosphorylation of $S_{1280}$, the binding of PACS proteins to TRPM3 channels may account for a reduced presence of TRPM3 channels at the plasma membrane and a decreased TRPM3-mediated $\mathrm{Ca}^{2+}$ entry.

On the other hand, a direct interference with the functionality of TRPM3 channels may also explain the effects of $\mathrm{S}_{1280}$-phosphorylation upon TRPM3-dependent $\mathrm{Ca}^{2+}$ entry. The residue $S_{1280}$ is located in the cytosolic C-terminus of the TRPM3 protein in a domain that has not yet been attributed any specific function (Figure 3A,C). It lies close to the TRP domain that is highly conserved throughout all TRPV, TRPC and TRPM channels [40], pivotal for the gating of TRPV1 channels [41] and a target for the regulation of TRPM8 
channels by $\mathrm{PIP}_{2}$ [42]. Cryo-electron microscopy of the structurally related TRPM7 channel identified tryptophan $(\mathrm{W})$, lysine $(\mathrm{K})$, and arginine $(\mathrm{R})$ residues of the TRP domain-that are conserved in TRPM3-as interaction sites of $N$-terminal amino acids located immediately before the transmembrane helix S1and within the S4-S5 linker [27]. Based on this finding, the TRP domain and the S4-S5 linker have been proposed to "couple the movement of the voltage sensor like S1 to S4 domains to the channel gate" [27]. Also in close proximity but c-terminal to $S_{1280}$ of TRPM3 lies the connecting helix domain that is equally well conserved in TRPM1/3/6/7 proteins [27] (Figure 3A,C). This domain determines the interaction of the $N$ - and C-termini of TRPM7 proteins. Thus, phosphorylation of TRPM3 within a region between the TRP domain and the connecting helix domain might interfere with channel gating and or $N / C$ terminal interaction.

$\mathrm{S}_{1280}$ is not the subject of alternative splicing and is present in all TRPM3 variants described (Figure 3A, [26]). Therefore, its phosphorylation appears as a common mechanism to control all TRPM3 isoforms. Since we used both PS and CIM0216 for activation, short pore isoforms such as TRPM $3 \alpha 2$ as well as long pore isoforms such as TRPM $3 \alpha 1$ might be controlled by CK2-mediated phosphorylation in INS-1 cells [10]. In HEK $\alpha 2$ cells however, TRPM3 channels that are exclusively composed of short pore TRPM $3 \alpha 2$ channels displayed CK2-dependent control of $\mathrm{Ca}^{2+}$ entry. $\mathrm{S}_{1280}$ is also well conserved in human and murine TRPM3 proteins (not shown), suggesting similar functions in TRPM3 proteins of different species. Within the TRPM channel family, however, $S_{1280}$ is located within a heterogeneous region. Serine residues at homologous positions are absent in the closest relatives TRPM1 and TRPM6 or are not targets of CK2 in TRPM7 (Figure 3C). Thus, phosphorylation of the residue $S_{1280}$ by $C K 2$ appears to be a specific mechanism for the control of TRPM3 channels.

\subsection{Contribution of CK2-Mediated Phosphorylation of TRPM3 to the Control of Insulin Release}

A precise regulation of the insulin release from pancreatic $\beta$-cells is crucial for glucose homeostasis. Our previous data showed that TRPM3-deficient mice display impaired blood glucose clearance after glucose administration [4]. Accordingly, TRPM3 antagonists attenuated glucose-stimulated insulin secretion from INS-1 $\beta$-cells [43] and TRPM3-deficient INS-1 cells showed reduced $\mathrm{Ca}^{2+}$ entry and insulin release in response to PS and glucose [4]. Therefore, we proposed a significant role for TRPM3 in the control of glucose-stimulated insulin release (GSIS) [4]. Since inhibition of CK2 increases both cytosolic $\mathrm{Ca}^{2+}$ and GSIS [22] and-as we show now-phosphorylation by CK2 inhibits TRPM3-mediated $\mathrm{Ca}^{2+}$ entry, it is reasonable to propose that the CK2-mediated inhibition of TRPM3 plays a role in the control of GSIS. This hypothesis is in line with a number of other observations describing CK2 as a general inhibitor of insulin including CK2 phosphorylation of transcription factors to reduce insulin production and the phosphorylation of kinesin heavy chain and muscarinic receptors 3 to inhibit insulin release (reviewed in [44]). Very similar to TRPM3, we identified two serine residues of Cav2.1 channels as targets of CK2 phosphorylation and showed that CK2 inhibition of Cav channels is followed by increased intracellular $\mathrm{Ca}^{2+}$ and insulin release [22]. Thus, CK2 phosphorylation may limit $\mathrm{Ca}^{2+}$ entry through both channels and may provide a common mechanism to restrict $\mathrm{Ca}^{2+}$ entry and insulin release in B-cells. Accordingly, INS-1 cells displayed enhanced TRPM3-initiated (PS-stimulated) $\mathrm{Ca}^{2+}$ entry when CK2 was inhibited by CX-4945 and reduced TRPM3-dependent $\mathrm{Ca}^{2+}$ signals when CK2 was overexpressed (Figure 5). However, TRPM3 channels depolarize the membrane and consequently activate Cav channels so that both channels together contribute to $\mathrm{Ca}^{2+}$ entry and insulin release after TRPM3 activation [4]. Hitherto, the affinity of CK2 for both channels as well as their relative abundance inside the $\beta$-cell is unknown. Hence, the extent of the CK2-dependent inhibition of the individual channels remains an open question, and the data shown in Figure 5 do not allow conclusive statements about the relative contribution of CK2 phosphorylation of Cav and TRPM3 channels to TRPM3-initiated $\mathrm{Ca}^{2+}$ influx. 


\section{Materials and Methods}

\subsection{Cell Culture and Reagents}

If not otherwise indicated, commercial material was purchased from Fisher Scientific (Schwerte, Germany). HEK293 cells and HEK $\alpha 2$ cells [24] were cultured in Dulbecco's minimal essential medium at $37^{\circ} \mathrm{C}$ in a humidified atmosphere containing $5 \% \mathrm{CO}_{2}$ and were passaged twice a week. INS-1 cells [45] and the TRPM3-deficient INS-1 lines M3KO-1, M3KO-2, and M3KO-3 [4] were cultured as described [4]. A $10 \mathrm{mM}$ stock solution of the CK2 inhibitor CX-4945 or $100 \mathrm{mM}$ stock solutions of pregnenolone sulfate (PS) and CIM0216 were dissolved in dimethyl sulfoxide (DMSO, Merck, Darmstadt, Germany) and stored at $-20^{\circ} \mathrm{C}$. For use, the reagents were diluted in Krebs Ringer bicarbonate HEPES buffer (KRBH; $135 \mathrm{mM} \mathrm{NaCl}, 3.6 \mathrm{mM} \mathrm{KCl}, 5 \mathrm{mM} \mathrm{NaHCO}_{3}, 0.5 \mathrm{mM} \mathrm{NaH}_{2} \mathrm{PO}_{4}, 0.5 \mathrm{mM}$ $\mathrm{MgCl}_{2}, 1.5 \mathrm{mM} \mathrm{CaCl}_{2}, 10 \mathrm{mM}$ HEPES, 0.1\% BSA w/v, $290 \pm 5 \mathrm{mOsm} / \mathrm{L}, \mathrm{pH} 7.4$ ) to a final concentration as indicated in the figures and compared to controls with DMSO alone.

\subsection{Mutagenesis of TRPM3, Plasmids, Transfection, and Fluorescence-Activated Cell Sorting (FACS)}

The following oligonucleotide primers 5'GCG GAC CAG GAC GAA AGG GAC TAC G and 5'CTC ATG CTT CCT CCA CCG GC and the QuickChange site-directed mutagenesis kit (Agilent Technologies, Waldbronn, Germany) were used to exchange serine $_{1172}$ in TRPM $3 \alpha 2$ for alanine. The plasmids TRPM $3 \alpha 2$-IRESGFP [5] and TRPM $3 \alpha 2$ $\mathrm{S}_{1172} \mathrm{~A}$-IRESGFP allowing the bicistronic expression of TRPM3 and the EGFP cDNAs as well as the plasmid pEGFP-CK2 $\alpha$ encoding EGFP-CK2 $\alpha$ fusion proteins were transfected using Lipofectamine-2000 according to the manufacturer's instructions. For the experiment shown in Figure 4A, TRPM3-expressing cells were identified by the green fluorescence of the co-expressed green fluorescent protein (GFP) and isolated by fluorescence-activated cell sorting on a MoFlo XDP cell sorter (Beckman Coulter).

\subsection{Fura-2 $\mathrm{Ca}^{2+}$ Imaging}

$\mathrm{Ca}^{2+}$ imaging experiments were performed essentially as described [22]. In brief, 2-3 days after seeding on poly-L-lysine-coated glass coverslips, cells were loaded for 30 min at $37^{\circ} \mathrm{C}$ and $5 \% \mathrm{CO}_{2}$ with $5 \mu \mathrm{M}$ fura-2-acetoxymethyl ester (Fura-2AM)dissolved in $\mathrm{KRBH}$ buffer. In some experiments (Figures $2 \mathrm{~A}$ and $5 \mathrm{~A}$ ), the solution also contained 10 $\mu \mathrm{M}$ CX-4945 or solvent only (DMSO, control). Cells were washed twice and analyzed for $1 \mathrm{~min}$ in $300 \mu \mathrm{L} \mathrm{KRBH}$ buffer at room temperature by fluorescence excitation every $3 \mathrm{~s}$ at wavelengths $(\lambda)$ of 340 and $380 \mathrm{~nm}$ and detection of fluorescence emissions at $\lambda>510$ $\mathrm{nm}$. PS and CIM0216 (or solvent only as control) dissolved in $300 \mu \mathrm{L} \mathrm{KRBH} \mathrm{buffer} \mathrm{as} \mathrm{were}$ added as indicated in the figures.

\subsection{In Vitro Phosphorylation of Immunopurified Proteins}

HEK293 cells and HEK293 cells transiently transfected with the TRPM $3 \alpha 2$ cDNA were grown in $75 \mathrm{~cm}^{2}$ flasks to $\sim 80 \%$ confluency, washed with phosphate buffered saline, and frozen at $-80^{\circ} \mathrm{C}$. Proteins were extracted at $4{ }^{\circ} \mathrm{C}$ with $1 \mathrm{~mL}$ solubilization buffer containing $100 \mathrm{mM}$ HEPES, $\mathrm{pH} 7.5,150 \mathrm{mM} \mathrm{NaCl}, 1 \mathrm{mM} \mathrm{CaCl} 2,1 \%$ digitonin, and supplemented with cOmplete $^{\text {TM }}$ ULTRA Tablets EDTA-free protease inhibitors (Roche, Mannheim, Germany). Cell debris was removed by centrifugation $\left(100,000 \times g, 4^{\circ} \mathrm{C}\right)$, and extracts were subjected to immunoprecipitation. For that purpose, $100 \mu \mathrm{L}$ protein $\mathrm{G}$ Sepharose beads were equilibrated thrice in buffer before cell extracts were precleared over a period of $1 \mathrm{~h}$ at $4{ }^{\circ} \mathrm{C}$. The supernatant was incubated with $10 \mu \mathrm{g}$ of affinity-purified rat monoclonal anti-TRPM3 antibodies [8] or polyclonal TRPM3 antibodies [4] for $1 \mathrm{~h}$ at $4{ }^{\circ} \mathrm{C}$ and subsequently added to another aliquot of equilibrated protein $\mathrm{G}$ Sepharose. Immunoprecipitation was continued overnight with gentle shaking at $4{ }^{\circ} \mathrm{C}$, before the beads were washed three times. Bound proteins were resuspended in $20 \mu \mathrm{L}$ kinase buffer $(50 \mathrm{mM}$ Tris- $\mathrm{HCl}, \mathrm{pH} 7.5,100 \mathrm{mM} \mathrm{NaCl}$, $10 \mathrm{mM} \mathrm{MgCl} 2,1 \mathrm{mM}$ dithiothreitol, $50 \mu \mathrm{M}$ ATP) and incubated at $37^{\circ} \mathrm{C}$ for $30 \mathrm{~min}$ with $185 \mathrm{kBq}\left[\gamma^{32} \mathrm{P}\right] \mathrm{ATP}$ or $\left[\gamma^{-}{ }^{32} \mathrm{P}\right] \mathrm{GTP}$ (Hartmann Analytic, Braunschweig, Germany) in the 
presence or absence of $0.4 \mu \mathrm{g}$ purified, recombinant CK2 $(0.4 \mu \mathrm{g} / \mu \mathrm{L})$ [46]. Nucleolin served as a control substrate in a separate reaction. The reactions were stopped by the addition of $3 \times$ SDS sample buffer (195 mM Tris-HCl, pH 6.8, 6\% SDS, 15\% $\beta$-mercaptoethanol, 30\% glycerol, $0.03 \%$ bromophenol blue) at $95^{\circ} \mathrm{C}$ for $5 \mathrm{~min}$. Finally, proteins were separated in a $7.5 \%$ SDS polyacrylamide gel. The gel was dried under vacuum and analyzed by autoradiography (Carestream ${ }^{\circledR}$ X-Omat LS film, Sigma-Aldrich, Munich, Germany).

For immunoblot analysis of phosphorylated protein with a phospho-CK2 substrate motif antibody (Cell Signaling \#8738), extraction, immunoprecipitation, phosphorylation using GTP, and SDS PAGE were performed as described above. Proteins were blotted to a PVDF membrane, and the membrane was incubated in Tris-buffered saline (TBS, $20 \mathrm{mM}$ Tris- $\mathrm{HCl}, \mathrm{pH} 7.4,150 \mathrm{mM} \mathrm{NaCl}$ ) with $0.1 \%$ Tween 20 (TBS-T) and 5\% bovine serum albumin (BSA) for one hour at room temperature. Incubation with the phospho-CK2 substrate motif antibody was performed in a dilution of $1: 1000$ in TBS-T/5\% BSA at $4{ }^{\circ} \mathrm{C}$ overnight. The membrane was washed twice for $10 \mathrm{~min}$ with TBS-T, incubated with a peroxidase-coupled secondary anti-rabbit antibody for $1 \mathrm{~h}$ at room temperature and washed again twice for 10 min with TBS-T before phosphorylated proteins were visualized using the SuperSignal ${ }^{\mathrm{TM}}$ West Femto Maximum Sensitivity Substrate.

\subsection{In Vitro Phosphorylation of a TRPM3 Peptide Library}

Pentadecapeptides were synthesized on polyethlylene-glycol-derivatized cellulose membranes (amino-PEG500-UC540, Intavis, Cologne, Germany) using an Intavis ResPepSL peptide spot synthesizer. The filters were equilibrated in kinase buffer $(50 \mathrm{mM}$ Tris- $\mathrm{HCl}$, pH 7.5, $100 \mathrm{mM} \mathrm{NaCl}, 10 \mathrm{mM} \mathrm{MgCl}, 1 \mathrm{mM}$ dithiothreitol, $50 \mu \mathrm{M}$ ATP) supplemented with $1 \%$ bovine serum albumin (BSA) overnight at $4{ }^{\circ} \mathrm{C}$, incubated for one hour at room temperature in $2 \mathrm{~mL}$ kinase buffer containing $740 \mathrm{kBq}\left[\gamma^{-32} \mathrm{P}\right]$ ATP in the presence or absence of recombinant $\mathrm{CK} 2$ before they were washed three times with kinase buffer containing $1 \mathrm{M}$ $\mathrm{NaCl}$. Bound proteins were removed with $8 \mathrm{M}$ urea, $35 \mathrm{mM}$ SDS, and 1\% 2-mercaptoethanol. Finally, the membranes were washed with ethanol and dried. Phosphorylated peptides were visualized using autoradiography.

Author Contributions: Conceptualization, S.E.P.; funding acquisition, C.G., M.M. and S.E.P.; investigation, A.B., C.G. and S.E.P., methodology, A.B., C.G. and S.E.P.; supervision, S.E.P.; visualization A.B. and S.E.P., writing-original draft, S.E.P.; writing-review and editing, C.G., M.M. and S.E.P. All authors have read and agreed to the published version of the manuscript.

Funding: This work was supported by the Dr. Rolf M. Schwiete Stiftung, Mannheim, Germany, project no. 06/2015 to C.G. and M.M. and project no. 2020-006 to C.G. and by grants from the Deutsche Forschungsgemeinschaft (CRC 894) and the Medical Faculty of Saarland University (HOMFOR) to S.E.P.

Acknowledgments: We thank Ute Soltek, Heidi Löhr, and Martin Simon-Thomas for excellent technical support.

Conflicts of Interest: The authors declare no conflict of interest. The funders had no role in the design of the study; in the collection, analyses, or interpretation of data; in the writing of the manuscript; or in the decision to publish the results.

\section{References}

1. Klec, C.; Ziomek, G.; Pichler, M.; Malli, R.; Graier, W.F. Calcium Signaling in B-cell Physiology and Pathology: A Revisit. Int. J. Mol. Sci. 2019, 20, 6110. [CrossRef]

2. Yang, S.-N.; Shi, Y.; Yang, G.; Li, Y.; Yu, J.; Berggren, P.-O. Ionic mechanisms in pancreatic $\beta$ cell signaling. Cell. Mol. Life Sci. 2014, 71, 4149-4177. [CrossRef]

3. Catterall, W.A.; Wisedchaisri, G.; Zheng, N. The chemical basis for electrical signaling. Nat. Chem. Biol. 2017, 13, 455-463. [CrossRef] [PubMed]

4. Becker, A.; Mannebach, S.; Mathar, I.; Weissgerber, P.; Freichel, M.; Loodin, A.P.; Fecher-Trost, C.; Belkacemi, A.; Beck, A.; Philipp, S.E. Control of Insulin Release by Transient Receptor Potential Melastatin 3 (TRPM3) Ion Channels. Cell. Physiol. Biochem. 2020, 54, 1115-1131. [CrossRef] 
5. Oberwinkler, J.; Lis, A.; Giehl, K.M.; Flockerzi, V.; Philipp, S.E. Alternative Splicing Switches the Divalent Cation Selectivity of TRPM3 Channels. J. Biol. Chem. 2005, 280, 22540-22548. [CrossRef]

6. Grimm, C.; Kraft, R.; Sauerbruch, S.; Schultz, G.; Harteneck, C. Molecular and Functional Characterization of the Melastatinrelated Cation Channel TRPM3. J. Biol. Chem. 2003, 278, 21493-21501. [CrossRef] [PubMed]

7. Lee, N.; Chen, J.; Sun, L.; Wu, S.; Gray, K.R.; Rich, A.; Huang, M.; Lin, J.-H.; Feder, J.N.; Janovitz, E.B.; et al. Expression and Characterization of Human Transient Receptor Potential Melastatin 3 (hTRPM3). J. Biol. Chem. 2003, 278, 20890-20897. [CrossRef]

8. Wagner, T.F.; Loch, S.; Lambert, S.; Straub, I.; Mannebach, S.; Mathar, I.; Düfer, M.; Lis, A.; Flockerzi, V.; Philipp, S.E.; et al. Transient receptor potential M3 channels are ionotropic steroid receptors in pancreatic $\beta$ cells. Nat. Cell Biol. 2008, 10, $1421-1430$. [CrossRef]

9. Held, K.; Kichko, T.; De Clercq, K.; Klaassen, H.; Van Bree, R.; Vanherck, J.-C.; Marchand, A.; Reeh, P.; Chaltin, P.; Voets, T.; et al. Activation of TRPM3 by a potent synthetic ligand reveals a role in peptide release. Proc. Natl. Acad. Sci. USA 2015, 112, E1363-E1372. [CrossRef] [PubMed]

10. Held, K.; Aloi, V.D.; Freitas, A.C.N.; Janssens, A.; Segal, A.; Przibilla, J.; Philipp, S.E.; Wang, Y.T.; Voets, T.; Vriens, J. Pharmacological properties of TRPM3 isoforms are determined by the length of the pore loop. Br. J. Pharmacol. in press. 2020. [CrossRef]

11. Tóth, B.I.; Konrad, M.; Ghosh, D.; Mohr, F.; Halaszovich, C.R.; Leitner, M.; Vriens, J.; Oberwinkler, J.; Voets, T. Regulation of the transient receptor potential channel TRPM3 by phosphoinositides. J. Gen. Physiol. 2015, 146, 51-63. [CrossRef]

12. Badheka, D.; Borbiro, I.; Rohacs, T. Transient receptor potential melastatin 3 is a phosphoinositide-dependent ion channel. J. Gen. Physiol. 2015, 146, 65-77. [CrossRef]

13. Przibilla, J.; Dembla, S.; Rizun, O.; Lis, A.; Jung, M.; Oberwinkler, J.; Beck, A.; Philipp, S.E. Ca2+-dependent regulation and binding of calmodulin to multiple sites of Transient Receptor Potential Melastatin 3 (TRPM3) ion channels. Cell Calcium 2018, 73 , 40-52. [CrossRef] [PubMed]

14. Holakovska, B.; Grycova, L.; Jirku, M.; Sulc, M.; Bumba, L.; Teisinger, J. Calmodulin and S100A1 Protein Interact with N Terminus of TRPM3 Channel. J. Biol. Chem. 2012, 287, 16645-16655. [CrossRef]

15. Koivisto, A.-P.; Belvisi, M.G.; Gaudet, R.; Szallasi, A. Advances in TRP channel drug discovery: From target validation to clinical studies. Nat. Rev. Drug Discov. 2021, 1-19. [CrossRef]

16. Dembla, S.; Behrendt, M.; Mohr, F.; Goecke, C.; Sondermann, J.; Schneider, F.M.; Schmidt, M.; Stab, J.; Enzeroth, R.; Leitner, M.G.; et al. Anti-nociceptive action of peripheral mu-opioid receptors by G-beta-gamma protein-mediated inhibition of TRPM3 channels. eLife 2017, 6, 26280. [CrossRef]

17. Badheka, D.; Yudin, Y.; Borbiro, I.; Hartle, C.M.; Yazici, A.; Mirshahi, T.; Rohacs, T. Inhibition of Transient Receptor Potential Melastatin 3 ion channels by G-protein $\beta \gamma$ subunits. eLife 2017, 6, e26147. [CrossRef] [PubMed]

18. Quallo, T.; Alkhatib, O.; Gentry, C.; A Andersson, D.; Bevan, S. G protein $\beta \gamma$ subunits inhibit TRPM3 ion channels in sensory neurons. eLife 2017, 6, e26138. [CrossRef] [PubMed]

19. Alkhatib, O.; Da Costa, R.; Gentry, C.; Quallo, T.; Mannebach, S.; Weissgerber, P.; Freichel, M.; Philipp, S.E.; Bevan, S.; Andersson, D.A. Promiscuous G-Protein-Coupled Receptor Inhibition of Transient Receptor Potential Melastatin 3 Ion Channels by G $\beta \gamma$ Subunits. J. Neurosci. 2019, 39, 7840-7852. [CrossRef]

20. Vriens, J.; Owsianik, G.; Hofmann, T.; Philipp, S.E.; Stab, J.; Chen, X.; Benoit, M.; Xue, F.; Janssens, A.; Kerselaers, S.; et al. TRPM3 Is a Nociceptor Channel Involved in the Detection of Noxious Heat. Neuron 2011, 70, 482-494. [CrossRef] [PubMed]

21. Wagner, T.F.J; Drews, A.; Loch, S.; Mohr, F.; Philipp, S.E.; Lambert, S.; Oberwinkler, J. TRPM3 channels provide a regulated influx pathway for zinc in pancreatic beta cells. Pflüger's Arch. Gesamte Physiol. Menschen Tiere 2010, 460, 755-765. [CrossRef] [PubMed]

22. Scheuer, R.; Philipp, S.E.; Becker, A.; Nalbach, L.; Ampofo, E.; Montenarh, M.; Götz, C. Protein Kinase CK2 Controls Cav2.1Dependent Calcium Currents and Insulin Release in Pancreatic $\beta$-Cells. Int. J. Mol. Sci. 2020, 21, 4668. [CrossRef]

23. Allende, J.E.; Allende, C.C. Protein kinase CK2: An enzyme with multiple substrates and a puzzling regulation. FASEB J. 1995, 9 , 313-323. [CrossRef] [PubMed]

24. Frühwald, J.; Londoño, J.C.; Dembla, S.; Mannebach, S.; Lis, A.; Drews, A.; Wissenbach, U.; Oberwinkler, J.; Philipp, S.E. Alternative Splicing of a Protein Domain Indispensable for Function of Transient Receptor Potential Melastatin 3 (TRPM3) Ion Channels. J. Biol. Chem. 2012, 287, 36663-36672. [CrossRef]

25. Ampofo, E.; Kietzmann, T.; Zimmer, A.; Jakupovic, M.; Montenarh, M.; Götz, C. Phosphorylation of the von Hippel-Lindau protein (VHL) by protein kinase CK2 reduces its protein stability and affects p53 and HIF-1 $\alpha$ mediated transcription. Int. J. Biochem. Cell Biol. 2010, 42, 1729-1735. [CrossRef]

26. Oberwinkler, J.; Philipp, S.E. TRPM3. In Mediators and Drugs in Gastrointestinal Motility I; Springer: Berlin/Heidelberg, Germany, 2014; Volume 222, pp. 427-459. [CrossRef]

27. Duan, J.; Li, Z.; Li, J.; Hulse, R.; Santa-Cruz, A.; Valinsky, W.C.; Abiria, S.A.; Krapivinsky, G.; Zhang, J.; Clapham, D.E. Structure of the mammalian TRPM7, a magnesium channel required during embryonic development. Proc. Natl. Acad. Sci. USA 2018, 115, E8201-E8210. [CrossRef]

28. Fujiwara, Y.; Minor, D.L. X-ray Crystal Structure of a TRPM Assembly Domain Reveals an Antiparallel Four-stranded Coiled-coil. J. Mol. Biol. 2008, 383, 854-870. [CrossRef] [PubMed]

29. Cao, D.-S.; Zhong, L.; Hsieh, T.-H.; Abooj, M.; Bishnoi, M.; Hughes, L.; Premkumar, L.S. Expression of Transient Receptor Potential Ankyrin 1 (TRPA1) and Its Role in Insulin Release from Rat Pancreatic Beta Cells. PLOS ONE 2012, 7, e38005. [CrossRef] 
30. Yao, X.; Kwan, H.-Y.; Huang, Y. Regulation of TRP Channels by Phosphorylation. Neurosignals 2005, 14, 273-280. [CrossRef]

31. Broertjes, J.; Klarenbeek, J.; Habani, Y.; Langeslag, M.; Jalink, K. TRPM7 residue S1269 mediates cAMP dependence of Ca2+ influx. PLOS ONE 2019, 14, e0209563. [CrossRef]

32. Nilius, B.; Prenen, J.; Tang, J.; Wang, C.; Owsianik, G.; Janssens, A.; Voets, T.; Zhu, M.X. Regulation of the Ca2+ Sensitivity of the Nonselective Cation Channel TRPM4. J. Biol. Chem. 2005, 280, 6423-6433. [CrossRef] [PubMed]

33. Cerda, O.; Cáceres, M.; Park, K.-S.; Leiva-Salcedo, E.; Romero, A.; Varela, D.; Trimmer, J.S.; Stutzin, A. Casein kinase-mediated phosphorylation of serine 839 is necessary for basolateral localization of the Ca2+-activated non-selective cation channel TRPM4. Pflüger's Arch. Gesamte Physiol. Menschen Tiere 2015, 467, 1723-1732. [CrossRef]

34. Rivera, B.; Moreno, C.; Lavanderos, B.; Hwang, J.Y.; Fernández-Trillo, J.; Park, K.-S.; Orio, P.; Viana, F.; Madrid, R.; Pertusa, M Constitutive phosphorylation as a key regulator of TRPM8 channel function. J. Neurosci. 2021, 41, 8475-84963. [CrossRef]

35. Sacco, F.; Humphrey, S.J.; Cox, J.; Mischnik, M.; Schulte, A.; Klabunde, T.; Schäfer, M.; Mann, M. Glucose-regulated and drug-perturbed phosphoproteome reveals molecular mechanisms controlling insulin secretion. Nat. Commun. 2016, 7, 13250. [CrossRef]

36. Han, H.; Moon, S.; Kim, Y.; Ho, W.-K.; Kim, K.; Kang, Y.; Jun, H.; Kim, Y. Comprehensive Phosphoproteome Analysis of INS-1 Pancreatic Beta-Cells using Various Digestion Strategies Coupled with Liquid Chromatography-Tandem Mass Spectrometry. J. Proteome Res. 2012, 11, 2206-2223. [CrossRef]

37. Meggio, F.; Marin, O.; A Pinna, L. Substrate specificity of protein kinase CK2. Cell. Mol. Boil. Res. 1994, 40, 401-409.

38. Rekha, N.; Srinivasan, N. Structural basis of regulation and substrate specificity of protein kinase CK2 deduced from the modeling of protein-protein interactions. BMC Struct. Biol. 2003, 3, 4. [CrossRef]

39. Köttgen, M.; Benzing, T.; Simmen, T.; Tauber, R.; Buchholz, B.; Feliciangeli, S.; Huber, T.B.; Schermer, B.; Kramer-Zucker, A.; Höpker, K.; et al. Trafficking of TRPP2 by PACS proteins represents a novel mechanism of ion channel regulation. EMBO J. 2005, 24, 705-716. [CrossRef] [PubMed]

40. Hellmich, U.A.; Gaudet, R. Structural Biology of TRP Channels. In Mediators and Drugs in Gastrointestinal Motility I; Springer: Berlin/Heidelberg, Germany, 2014; Volume 223, pp. 963-990. [CrossRef]

41. Gregorio-Teruel, L.; Valente, P.; Liu, B.; Fernández-Ballester, G.; Qin, F.; Ferrer-Montiel, A. The Integrity of the TRP Domain Is Pivotal for Correct TRPV1 Channel Gating. Biophys. J. 2015, 109, 529-541. [CrossRef]

42. Rohács, T.; Lopes, C.M.B.; Michailidis, I.; E Logothetis, D. PI(4,5)P2 regulates the activation and desensitization of TRPM8 channels through the TRP domain. Nat. Neurosci. 2005, 8, 626-634. [CrossRef] [PubMed]

43. Klose, C.; Straub, I.; Riehle, M.; Ranta, F.; Krautwurst, D.; Ullrich, S.; Meyerhof, W.; Harteneck, C. Fenamates as TRP channel blockers: Mefenamic acid selectively blocks TRPM3. Br. J. Pharmacol. 2011, 162, 1757-1769. [CrossRef] [PubMed]

44. Ampofo, E.; Nalbach, L.; Menger, M.D.; Montenarh, M.; Götz, C. Protein Kinase CK2-A Putative Target for the Therapy of Diabetes Mellitus? Int. J. Mol. Sci. 2019, 20, 4398. [CrossRef] [PubMed]

45. Asfari, M.; Janjic, D.; Meda, P.; Li, G.; A Halban, P.; Wollheim, C.B. Establishment of 2-mercaptoethanol-dependent differentiated insulin-secreting cell lines. Endocrinol. 1992, 130, 167-178. [CrossRef] [PubMed]

46. Grankowski, N.; Boldyreff, B.; Issinger, O.-G. Isolation and characterization of recombinant human casein kinase II subunits alpha and beta from bacteria. JBIC J. Biol. Inorg. Chem. 1991, 198, 25-30. [CrossRef] [PubMed] 